\title{
The Paracoccidioides cell wall: past and present layers toward understanding interaction with the host
}

\section{Rosana Puccia*, Milene Carmes Vallejo, Alisson Leonardo Matsuo and Larissa Valle Guilhen Longo}

Departamento de Microbiologia, Imunologia e Parasitologia, Universidade Federal de São Paulo - Escola Paulista de Medicina, São Paulo, Brazil

Edited by:

Marcio Rodrigues, Federal University of Rio de Janeiro, Brazil

\section{Reviewed by:}

Carol Munro, University of Aberdeen, UK

Jean Paul Latge, Institut Pasteur,

France

Walter Magliani, University of Parma, Italy

\section{*Correspondence:}

Rosana Puccia, Departamento de Microbiologia, Imunologia e

Parasitologia, Universidade Federal de

São Paulo - Escola Paulista de

Medicina, Rua Botucatu, 862, oitavo

andar, 04023-062 São Paulo, SP,

Brazil.

e-mail:rpuccia@unifesp.br;

ropuccia@gmail.com
The cell wall of pathogenic fungi plays import roles in the interaction with the host, so that its composition and structure may determine the course of infection. Here we present an overview of the current and past knowledge on the cell wall constituents of Paracoccidioides brasiliensis and $P$. lutzii. These are temperature-dependent dimorphic fungi that cause paracoccidioidomycosis, a systemic granulomatous, and debilitating disease. Focus is given on cell wall carbohydrate and protein contents, their immune-stimulatory features, adhesion properties, drug target characteristics, and morphological phase specificity. We offer a journey toward the future understanding of the dynamic nature of the cell wall and of the changes that may occur when the fungus infects the human host.

Keywords: cell wall, Paracoccidioides brasiliensis, P. lutzii, polysaccharides, adhesins, enzymes, host interaction
The 60s and 70s were prolific decades in the study of the morphological and biochemical aspects of the Paracoccidioides brasiliensis cell wall (San Blas and San Blas, 1984, 1994). This fungus belongs to a group of pathogens whose morphology changes according to the temperature of growth: a mycelial phase develops under mild environmental temperatures up to $26^{\circ} \mathrm{C}$, while multi-budding yeasts develop at temperatures near $37^{\circ} \mathrm{C}$. The infectious particles are supposedly inhaled conidia produced by environmental mycelia (Bustamante-Simon et al., 1985; San Blas, 1986; Samsonoff et al., 1991); transition to yeasts in the lungs is mandatory for the establishment of paracoccidioidomycosis (McEwen et al., 1987), which is a granulomatous mycosis prevalent in Latin America (San Blas et al., 2002). Currently, Paracoccidioides isolates from Brazilian central-western areas are considered a new species - P. lutzii ("Pb01-like"; Teixeira et al., 2009), whereas $P$. brasiliensis represents a complex of three phylogenetic groups (Matute et al., 2006). There is free access to complete genomic information for isolates $\mathrm{Pb} 18$, $\mathrm{Pb} 3$, and $\mathrm{Pb} 01$ at the Dimorphic Fungal Database of the Broad Institute site (http://www.broadinstitute.org/annotation/genome/ dimorph_collab/MultiHome.html), and genome comparative analyses have been reported (Desjardins et al., 2011). Transcriptome data have long been available for $\mathrm{Pb} 18$ and $\mathrm{Pb} 01$ and differentially expressed genes have been detected (Felipe et al., 2003, 2005; Goldman et al., 2003; Andrade et al., 2005; Nunes et al., 2005; Bailão et al., 2006; Borges et al., 2011). Yet, genetic manipulation in Paracoccidioides is only starting (Sturme et al., 2011), thus the association between translated proteins and the cell wall has generally been inferred by comparison with other fungal systems.
The relationship among P. brasiliensis cell wall, dimorphism, and virulence has intrigued pioneer researchers (San Blas, 1982). They used sophisticated high resolution microscopy and biochemical techniques available at the time to compare the surface structure of the yeast and budding forms (Carbonell, 1967), hyphae (Carbonell and Rodriguez, 1968), transition phases (Carbonell, 1969), isolated cell walls (Carbonell et al., 1970), and to identify the main cell wall components (Kanetsuna et al., 1969, 1972; Kanetsuna and Carbonell, 1970). They studied a Venezuelan fungal isolate whose cell wall was thicker in yeasts $(0.2-0.6 \mu \mathrm{m})$ than in hyphae $(80-150 \mathrm{~nm})$. Both showed a wide translucent and homogeneous layer that lied over the plasma membrane. In yeasts, an electron dense outer layer decorated with fibrils covered this inner layer. Conidia cell walls (150 to $300-\mathrm{nm}$ wide) were studied only later: they showed homogeneous appearance of medium electron density, being surrounded by a thick coat of long electron dense microfibrils (Edwards et al., 1991).

Carefully isolated yeast cell wall preparations were composed of around $81 \%$ carbohydrates (38\% hexoses; $43 \%$ amino sugars), $10 \%$ amino acids, and $11 \%$ lipids; for mycelia, these percentages were, respectively, $51 \%$ (38\% hexoses; $13 \%$ amino sugars), $33 \%$, and $8 \%$ (Kanetsuna et al., 1972). Isolated cell walls were biochemically fractionated into alkali-insoluble (F1) or alkali-soluble components precipitated (F2) or not (F3) upon neutralization with acetic acid. Striking structural differences were then observed (Kanetsuna et al., 1972): in yeasts, $95 \%$ of the glucans were $\alpha$-linked (F2) and $5 \%$ were $\beta$-linked (F1), while only $\beta$-linked glucans (F1) were found in mycelia. In both anomeric forms, long 1,3-linked chains were prevalent, with few 1,6-linked side chains. Chitin (F1) 
was more abundant in yeasts. Freeze-section-shadow techniques (Carbonell et al., 1970) revealed that F3, composed of galactomannan and amino acids, was amorphous. In yeasts, F2 contained only $\alpha$-1,3-glucans and appeared as thick ( $100 \mathrm{~nm})$ and short microfibrils that resembled the cell wall outer layer. F1, containing chitin, $\beta$-glucan, and amino acids, displayed delicate nets of irregularly disposed thin fibers $(20 \mathrm{~nm})$, similar to those seen in the cell wall inner layer. Successive treatments with $\mathrm{NaOH}, \beta$-1,3-glucanase and pronase damaged the mycelium cell wall, while the round yeast shape was maintained (Kanetsuna, 1981). The importance of randomly orientated chitin microfibrils for rigidity was then stressed. The round yeast shape was also kept in a mutant strain where most $\alpha$-glucan was replaced by 1,3-mannan, as well as in the parent strain that presented only reduced amounts of $\alpha$-glucan due to the effect of multiple sub-culturing (San Blas et al., 1976, 1977b). Later analysis of cell wall polysaccharides proved that their composition, however, could vary not only with culture conditions, but also among isolates (San Blas and Vernet, 1977; San Blas and San Blas, 1982; San Blas et al., 1984), and especially in mutants with defects in phase transition (San Blas et al., 1977a; Hallak et al., 1982; San Blas and San Blas, 1992). At that time, these mutants were useful to review the models of dimorphism (Kanetsuna et al., 1972; Kanetsuna, 1981; San Blas and San Blas, 1984, 1994). It has recently been reported that a few single residues of $\alpha$-1,4-linked glucose may be attached to the linear $\alpha-1,3$-glucan chains (Sorais et al., 2010).

Although a role for $\alpha$-glucan in the yeast shape was discarded, its relationship with fungal virulence has long been speculated, especially because decreased virulence and loss of externally arranged $\alpha$-glucan have been observed to occur concomitantly (San Blas et al., 1976, 1977b; San Blas and Vernet, 1977; Goihman-Yahr et al., 1980; Hallak et al., 1982; Brummer et al., 1990; Kashino et al., 1990). The role of fungal cell wall polysaccharides as pathogenassociated molecular patterns (PAMPs) has been widely explored in Candida albicans (Netea et al., 2008). $\beta$-glucan is a cell wall PAMP that is mainly recognized by macrophage dectin-1 (Brown et al., 2002) and may interact with TLR2 (toll-like receptor 2) to activate NF- $\kappa$ B signaling (Gantner et al., 2003). The role of external $\alpha$-glucan to prevent dectin- 1 recognition and stimulus of protective immune response has been recently demonstrated in genetically manipulated Histoplasma capsulatum (Rappleye et al., 2004, 2007). Dectin-1 activation by wild type P. brasiliensis has been suggested (Diniz et al., 2004), as well as cellular immunestimulatory responses by $P$. brasiliensis F1 cell wall fraction have been demonstrated (Silva and Fazioli, 1985; Alves et al., 1987; Silva et al., 1997, 2011; Anjos et al., 2002; de Pádua Queiroz et al., 2010). Cell wall F1 obtained from avirulent $P$. brasiliensis elicited in mice higher levels of tumor necrosis factor (TNF- $\alpha$; Figueiredo et al., 1993), leukocyte recruitment, and granuloma formation (Silva and Fazioli, 1985) when compared with F1 from a virulent isolate. The effects correlated with higher $\beta$-glucan levels in the cell wall of the avirulent yeasts. Therefore, the amount of both $\alpha$ - and $\beta$-glucans might contribute to differential virulence among Paracoccidioides isolates.

B-cell activation by $P$. brasiliensis cell wall fractions has also been reported (de Oliveira et al., 1993; Benard et al., 1995; Silva and Silva, 1995; Silva et al., 1997). Complement activation (Crott et al.,
1997) and neutrophil chemotaxis (Crott et al., 1993) stimulated by F1 have been observed. It has been demonstrated by immunofluorescence that C3, C3a, C3d, C3g, C4, C5b-9, and factors $\mathrm{H}$ and B are present on the cell surface of $P$. brasiliensis yeasts (Munk and Silva, 1992) and that complement 3 and mannose receptors are important for phagocytosis by macrophages (Jiménez et al., 2006). Also, an opsonized cell wall preparation was able to regulate B lymphocyte by complement receptors 1 and 2, which recognize activated C3 and C4 (de Agostino Biella et al., 2006). The results concerning stimulation with whole and fractionated cell wall preparations should be viewed critically, though, taking into consideration the purity of the preparations and the fact that F1 contains chitin, proteins, and $\beta$-glucans.

Water soluble galactomannan extracted in P. brasiliensis cell wall F3 (Kanetsuna et al., 1972) bears common antibody epitopes among dimorphs (Azuma et al., 1974). The galactomannan backbone has long $\alpha-1,6-\operatorname{Man} p$ chains, which in hyphae are mostly decorated with $\alpha-1,6-\operatorname{Man} p-\alpha-1,2-$ Gal $f$ ramifications (Ahrazem et al., 2003). In yeasts, these are minor structures, while $\beta-1,6-$ Galf- $\alpha-1,2-\operatorname{Man} p$ and $\alpha-1,2-\operatorname{Man} p$ prevail. Terminal $\beta$-galactofuranosyl residues are common fungal epitopes that can evoke cross-reactivity (Puccia and Travassos, 1991; Latge, 2009). Conversely, terminal $\alpha$-galactofuranose has seldom been described in fungi (San Blas et al., 2005). We have recently characterized $\alpha$-galactopyranosyl epitopes distributed along the cell wall and inside cytoplasmic vacuoles that were partially mapped in protein O-linked sugar chains (Vallejo et al., 2011). They are highly reactive with paracoccidioidomycosis patients' sera; however their role in the interaction with the host remains unknown. On the other hand, non-reducing units of terminal $N$-acetylneuraminic acid linked to sub-terminal $\beta$-galactopyranosyl units were observed on the yeast surface forming an anionic layer that possibly protects the fungus against phagocytosis (Soares et al., 1998). The nature of the glycoconjugates bearing these residues has not been described.

Cell wall-related sequences identified in the Paracoccidioides transcriptomes (Goldman et al., 2003; Felipe et al., 2005; Tomazett et al., 2005) and genomes (Desjardins et al., 2011) encode enzymes related to carbohydrate synthesis, remodeling, and degradation, as well as cell wall structural or associated molecules. A screening in the Pb01 transcriptome for GPI-anchored sequences (Castro et al., 2005) yielded six expression sequencing tags (ESTs) from possible cell wall structural proteins. A putative GPI-anchored membrane/cell wall $\beta$-1,3-glucan elongase capable of mediating fungal cell wall integrity ( $\mathrm{PbGel} 3 \mathrm{p})$ was immunolocalized at the yeast surface (Castro et al., 2009).

The structural uniqueness and essentiality of fungal cell wall components indicate that proteins involved in their synthesis/degradation are potential drug targets, e.g., $\alpha-1,3$-glucan synthase, glucanases [exo- $\beta-1,3$, endo- $\beta-1,3(4)], \alpha-1,2-$ and $\alpha$ 1,6-mannosyltransferases, chitinase, and dolichyl phosphate-Dmannose:protein $O$-D-mannosyltransferase (Desjardins et al., 2011). Paracoccidioides has a single $\beta$-1,3-glucan synthase gene that is overexpressed in $\mathrm{Pb} 01$ yeasts (Tomazett et al., 2010); however, echinocandin inhibitors of $\beta$-1,3-glucan synthesis have little effect against the yeast pathogenic phase due to the prevalence of $\alpha$-glucan (San Blas and Niño-Vega, 2008; Rodríguez-Brito et al., 2010). Thus, a better target would be $\alpha$-1,3-glucan synthase 
and its regulatory molecules including GTPase proteins Rho1, Rho2, Rac1, and Cdc42 (Sorais et al., 2010). Not coincidentally, $P$. brasiliensis mutants knocked down for CDC42 expression presented altered growth pattern and decreased virulence (Almeida et al., 2009).

Chitin synthases are broader targets for fungi. Genome analysis revealed the existence of seven chitin synthases in Paracoccidioides, one of each class, including a functional class III (Barreto et al., 2010), not described previously (Niño-Vega et al., 2000), and Pbrchs6 originally detected in transcriptome studies only in mycelia (Tomazett et al., 2005). Microarray hybridization analysis identified some chitin synthases up-regulated during the mycelium-to-yeast transition, while chitinases and endochitinases were downregulated (Nunes et al., 2005). A chitin deacetylase transcript $(C D A)$, which encodes an enzyme that converts chitin to chitosan, was overexpressed in Pb01 yeasts (Felipe et al., 2005).

A number of intracellular proteins, particularly enzymes, have also been localized to the cell wall in Paracoccidioides and other fungi (Nombela et al., 2006). Their presumptive roles at the surface might involve essential activities like cell wall biosynthesis and remodeling, microorganism adaptation to different conditions, and also interaction with the host. We reported on a mitochondrial heat-shock chaperone Mdj1 labeled at the P. brasiliensis yeast cell wall (Batista et al., 2006, 2007), which is the preferential site in fully formed mycelia (Dourado et al., unpublished). Alkaline phosphatase activity on the cell wall was demonstrated by histochemical techniques in P. brasiliensis yeast phase (Campo-Aasen and Albornoz, 1994). A secreted 75-kDa protein with phosphatase activity was identified by confocal microscopy and flow cytometry on the cell surface, preferentially at the budding site of $P$. brasiliensis (Xander et al., 2007). Yeast cells opsonized with anti-75 kDa monoclonal antibodies showed growth inhibition, increasing phagocytic index, and in vivo protection against murine paracoccidioidomycosis. Formamidase, which participates in the nitrogen metabolism, was detected by immunoelectron microscopy on the cell wall of Pb01 yeast cells (Borges et al., 2009), as well as a 66-kDa secreted aspartyl protease (PbSAP) that was more abundantly expressed in the yeast phase (Tacco et al., 2009).

Adhesion of pathogens to host components is an important step in microorganism infection and dissemination. The dataset of a recently developed Fungal RV adhesin predictor algorithm (Chaudhuri et al., 2011) identified 27 proteins from $P$. lutzii (Pb01). Among them, only triosephosphate isomerase and glyceraldehyde-3-phosphate dehydrogenase (GADPH), two cytoplasmic glycolytic enzymes, have already been identified as cell wall adhesins (Barbosa et al., 2006; Pereira et al., 2007). Both can bind to cell culture pneumocytes and to proteins associated with the extracellular matrix (ECM). Similar results have been observed for glyoxylate pathway malate synthase (da Silva Neto et al., 2009) and for putative $\alpha-1,6$-mannosidase PbDfg5p (defective for filamentous growth protein), both localizing mainly to budding yeast cell walls (da Silva et al., 2008). PbDfg5p transcripts were preferentially expressed in yeasts, where it was shown to be linked to $\beta$-glucan. Enolase is another glycolytic enzyme with fibronectin-binding features and double localization in P. brasiliensis (Donofrio et al., 2009; Nogueira et al., 2010). This protein is also capable of activating plasminogen conversion to plasmin, a serine protease that can facilitate pathogen dissemination. Host cell exposure to recombinant enolase had enhanced fungal adhesion, possibly due to an increased exposure of $N$-acetylglucosamine, which might be recognized by paracoccin, a TNF- $\alpha$ stimulatory lectin (Coltri et al., 2006). Paracoccin is a cell wall chitin-binding protein with $N$ acetyl- $\beta$-D-glucosaminidase activity that plays a role in fungal growth, supposedly by participating in cell wall remodeling and organization (Ganiko et al., 2007; dos Reis Almeida et al., 2010).

Secreted gp43 is a major diagnostic P. brasiliensis antigen (Puccia and Travassos, 1991) that partly resides on the cell wall (Straus et al., 1996). It presents vaccine features due to the presence of Tcell epitopes that stimulate Th-1 protective responses (Taborda et al., 1998; Travassos et al., 2008), but apparently it can also stimulate innate immunity (Nakaira-Takahagi et al., 2011). Gp43 has been appointed as a virulence factor considering its broadly demonstrated adhesive properties to ECM (Vicentini et al., 1994; Gesztesi et al., 1996; Hanna et al., 2000), while an internal peptide (NLGRDAKRHL) was able to compete in binding assays (MendesGiannini et al., 2006). A 32-kDa ligand to laminin, fibronectin, and fibrinogen was observed on the surface of yeasts, mycelia, and conidia, which could play a role in the initial attachment of the infectious particles to the lungs (González et al., 2005, 2008). In general, experimental data have positively correlated fungal

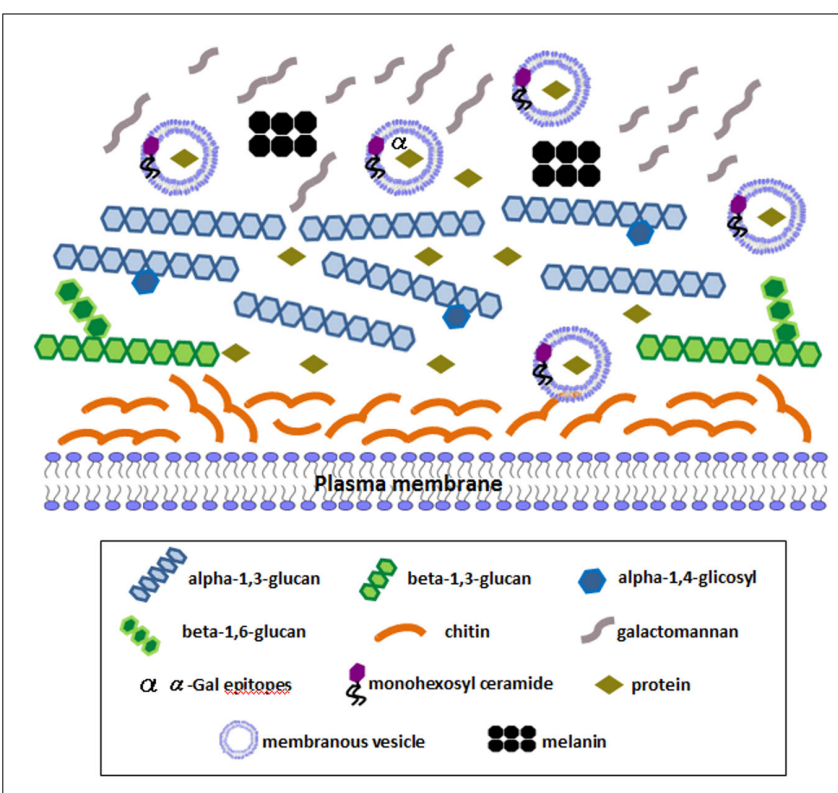

FIGURE 1 | Schematic representation of an updated view of Paracoccidioides yeast phase cell wall components. Structural polysaccharides are represented: an outer layer of alpha-1,3-glucan (with eventual single alpha-1,4-linked glucose residues) in higher amounts than beta-1,3-glucan, which lies in internal layers and is decorated with small beta-1,6-glucan side chains. Internal chitin fibers maintain the round shape and galactomannan composes an external fibrillar layer. Melanin is shown on the surface. Extracellular membranous vesicles containing monohexosyl ceramide transport components outside the plasma membrane, including numerous intracellular proteins. A number of intracellular proteins that have been immunolocalized to the cell wall in yeast cells using TEM or confocal microscopy (see text) are represented, as well as $\alpha$-Gal epitopes. Some of them have also been detected in isolated extracellular vesicles, like enolase, GADPH, formamidase, and triosephosphate isomerase. 
adhesion with the degree of virulence among isolates (Hanna et al., 2000), and also with in vivo passage (Mendes-Giannini et al., 2006): higher expression of the 30-kDa laminin-binding protein (Andreotti et al., 2005) and enolase (Donofrio et al., 2009) was observed in the latter situation, suggesting once again the induction of cell wall virulence factors within the host or in host-like culture conditions.

Apart from polysaccharides and (glyco)proteins, the negatively charged pigment melanin was found in vitro and in vivo in the $P$. brasiliensis conidia and yeast cell wall (Gómez et al., 2001), conferring resistance to phagocytosis, antifungal drugs, and antimicrobial oxidants (da Silva et al., 2006, 2009). Data on the composition of cell wall lipids are hard to find, although early works reported up to $80 \%$ of lipids in the cell wall F3 fraction of highly subcultured and mutant $P$. brasiliensis strains (San Blas et al., 1976, 1977a). Neutral and acidic glycosphingolipids, specifically glucosylceramide (GlcCer) and glycoinositol phosphoryl-ceramides (GIPCs), have later been fully characterized and found to probably interfere in dimorphism; they bear antigenic oligosaccharide epitopes and present surface localization, possibly residing on the cell wall (Toledo et al., 2001, 2010; Bertini et al., 2007; Takahashi et al., 2009). In C. neoformans, a similar GlcCer was localized to the cell wall and correlated with cell wall thickening; anti-GlcCer antibodies were able to inhibit fungal growth and budding (Rodrigues et al., 2000). Later, this component was observed in vesicle membranes that crossed the cell wall toward the extracellular compartment of C. neoformans (Rodrigues et al., 2007).

We have recently characterized extracellular membranous vesicles in the yeast phase of $P$. brasiliensis (Vallejo et al., 2011), where a monohexosyl ceramide has also been detected (Vallejo et al.,

\section{REFERENCES}

Ahrazem, O., Prieto, A., San Blas, G., Leal, J. A., Jimenez-Barbero, J., and Bernabé, M. (2003). Structural differences between the alkaliextracted water-soluble cell wall polysaccharides from mycelial and yeast phases of the pathogenic dimorphic fungus Paracoccidioides brasiliensis. Glycobiology 13, 743-747.

Albuquerque, P. C., Nakayasu, E. S., Rodrigues, M. L., Frases, S., Casadevall, A., Zancope-Oliveira, R. M., Almeida, I. C., and Nosanchuk, J. D. (2008). Vesicular transport in Histoplasma capsulatum: an effective mechanism for trans-cell wall transfer of proteins and lipids in ascomycetes. Cell. Microbiol. 10, 1695-1710.

Almeida, A. J., Cunha, C., Carmona, J. A., Sampaio-Marques, B., Carvalho, A., Malavazi, I., Steensma, H. Y., Johnson, D. I., Leão, C., Logarinho, E., Goldman, G. H., Castro, A. G., Ludovico, P., and Rodrigues, F. (2009). Cdc42p controls yeast-cell shape and virulence of Paracoccidioides brasiliensis. Fungal Genet. Biol. 46, 919-926.
Alves, L. M., Figueiredo, F., Brandão Filho, S. L., Tincani, I., and Silva, C. L. (1987). The role of fractions from Paracoccidioides brasiliensis in the genesis of inflammatory response. Mycopathologia 97, 3-7.

Andrade, R. V., da Silva, S. P., Torres, F. A., Pocas-Fonseca, M. J., SilvaPereira, I., Maranhão, A. Q., Campos, E. G., Moraes, L. M., Jesuíno, R. S., Pereira, M., Soares, C. M., Walter, M. E., Carvalho, M. J., Almeida, N. F., Brigido, M. M., and Felipe, M. S. (2005). Overview and perspectives on the transcriptome of Paracoccidioides brasiliensis. Rev. Iberoam. Micol. 22, 203-212.

Andreotti, P. F., da Silva, J. L. M., Bailão, A. M., Soares, C. M., Benard, G., Soares, C. P., and MendesGiannini, M. J. (2005). Isolation and partial characterization of a $30 \mathrm{kDa}$ adhesin from Paracoccidioides brasiliensis. Microbes Infect. 7, 875-881.

Anjos, A. R., Calvi, S. A., Ferracini, R., Peraçoli, M. T., Silva, C. L., and Soares, A. M. (2002). Role of Paracoccidioides brasiliensis cell wall fraction containing beta-glucan in tumor necrosis factor-alpha

unpublished). They carry antigens recognized by patients' sera, including components containing $\alpha$-galactopyranosyl epitopes (Vallejo et al., 2011), macrophage stimulatory molecules (Vallejo et al., unpublished), and a large number of proteins recently identified using proteomic approaches (Vallejo et al., submitted). Among them are some of the proteins mentioned above to be localized to the cell wall and also surface proteins mildly extracted from $P$. brasiliensis cells (Longo et al., unpublished). Besides, over $40 \%$ of these proteins have orthologs among fungal vesicle proteins (Vallejo et al., submitted; Rodrigues et al., 2007; Albuquerque et al., 2008; Oliveira et al., 2010). In fungi, membranous extracellular vesicles seem to have several possible biogenesis routes; therefore they contain proteins of diverse nature (Casadevall et al., 2009; Oliveira et al., 2010). At least part of vesicle components could remain in the cell wall and be functional. An updated scheme of the Paracoccidioides cell wall, yeast phase, is presented in Figure 1 that considers past and recent findings of cell wall components discussed in this review. It is a future challenge to understand the transport of components outside the plasma membrane using non-conventional pathways, how they interact with structural cell wall molecules and interfere in its biology. These findings will help to update our view of the dynamic nature of this essential organelle and of the changes that may occur when the fungus infects the human host.

\section{ACKNOWLEDGMENTS}

The authors receive financial support from Fundação de Amparo à Pesquisa (FAPESP, Brazil), Conselho Nacional de Desenvolvimento Científico e Tecnológico (CNPq, Brazil), and Coordenação de Aperfeiçoamento de Pessoal de Nível Superior (CAPES, Brazil).

production by human monocytes: correlation with fungicidal activity. Med. Mycol. 40, 377-382.

Azuma, I., Kanetsuna, F., Tanaka, Y., Yamamura, Y., and Carbonell, L. M. (1974). Chemical and immunological properties of galactomannans obtained from Histoplasma duboisii, Histoplasma capsulatum, Paracoccidioides brasiliensis and Blastomyces dermatitidis. Mycopathol. Mycol. Appl. 54, 111-125.

Bailão, A. M., Schrank, A., Borges, C. L., Dutra, V., Molinari-Madlum, E. E. W. I., Felipe, M. S. S., MendesGiannini, M. J. S., Martins, W. S., Pereira, M., and Soares, C. M. A. (2006). Differential gene expression by Paracoccidioides brasiliensis in host interaction conditions: representational difference analysis identifies candidate genes associated with fungal pathogenesis. Microbes Infect. 8, 2686-2697.

Barbosa, M. S., Bao, S. N., Andreotti, P. F., de Faria, F. P., Felipe, M. S., dos Santos, F. L., Mendes-Giannini, M. J., and Soares, C. M. (2006). Glyceraldehyde-3-phosphate dehydrogenase of Paracoccidioides brasiliensis is a cell surface protein involved in fungal adhesion to extracellular matrix proteins and interaction with cells. Infect. Immun. 74, 382-389.

Barreto, L., Sorais, F., Salazar, V., San Blas, G., and Niño-Vega, G. A (2010). Expression of Paracoccidioides brasiliensis CHS3 in a Saccharomyces cerevisiae chs 3 null mutant demonstrates its functionality as a chitin synthase gene. Yeast 27, 293-300.

Batista, W. L., Barros, T. F., Goldman, G. H., Morais, F. V., and Puccia, R. (2007). Identification of transcription elements in the $5^{\prime}$ intergenic region shared by LON and MDJ1 heat shock genes from the human pathogen Paracoccidioides brasiliensis. Evaluation of gene expression. Fungal Genet. Biol. 44, 347-356.

Batista, W. L., Matsuo, A. L., Ganiko, L., Barros, T. F., Veiga, T. R., Freymüller, E., and Puccia, R. (2006). The PbMDJ1 gene belongs to a conserved MDJ1/LON locus in thermodimorphic pathogenic fungi and encodes a heat shock protein that localizes to both the mitochondria and cell wall of Paracoccidioides brasiliensis. Eukaryotic Cell 5, 379-390. 
Benard, G., Durandy, A., Assis, C. M., Hong, M. A., Orii, N. M., Sato, M. N., Mendes-Gianini, M. J., Lacaz, C. S., and Duarte, A. J. (1995). Responses of T and B lymphocytes to a Paracoccidioides brasiliensis cell wall extract in healthy sensitized and nonsensitized subjects. Am. J. Trop. Med. Hyg. 53, 189-194.

Bertini, S., Colombo, A. L., Takahashi, H. K., and Straus, A. H. (2007). Expression of antibodies directed to Paracoccidioides brasiliensis glycosphingolipids during the course of paracoccidioidomycosis treatment. Clin. Vaccine Immunol. 14, 150-156.

Borges, C. L., Bailão, A. M., Bao, S. N., Pereira, M., Parente, J. A., and Soares, C. M. A. (2011). Genes potentially relevant in the parasitic phase of the fungal pathogen Paracoccidioides brasiliensis. Mycopathologia 171, 1-9.

Borges, C. L., Parente, J. A., Barbosa, M. S., Santana, J. M., Bao, S. N., de Sousa, M. V., and Soares, C. M. A. (2009). Detection of a homotetrameric structure and proteinprotein interactions of Paracoccidioides brasiliensis formamidase lead to new functional insights. FEMS Yeast Res. 10, 104-113.

Brown, G. D., Taylor, P. R., Reid, D. M., Willment, J. A., Williams, D. L., Martinez-Pomares, L., Wong, S. Y., and Gordon, S. (2002). Dectin1 is a major beta-glucan receptor on macrophages. J. Exp. Med. 196, 407-412.

Brummer, E., Restrepo, A., Hanson, L. H., and Stevens, D. A. (1990). Virulence of Paracoccidiodes brasiliensis: the influence of in vitro passage and storage. Mycopathologia 109, 13-17.

Bustamante-Simon, B., McEwen, J. G., Tabares, A. M., Arango, M., and Restrepo-Moreno, A. (1985). Characteristics of the conidia produced by the mycelial form of Paracoccidioides brasiliensis. Sabouraudia 23, 407-414.

Campo-Aasen, I., and Albornoz, M. C. (1994). Alkaline phosphatase at the cell wall of the yeast phase of Paracoccidioides brasiliensis. Mycopathologia 127, 69-71.

Carbonell, L. M. (1967). Cell wall changes during the budding process of Paracoccidioides brasiliensis and Blastomyces dermatitidis. J. Bacteriol. 94, 213-223.

Carbonell, L. M. (1969). Ultrastructure of dimorphic transformation in Paracoccidioides brasiliensis. J. Bacteriol. 100, 1076-1082.

Carbonell, L. M., Kanetsuna, F., and Gil, F. (1970). Chemical morphology of glucan and chitin in the cell wall of the yeast phase of Paracoccidioides brasiliensis. J. Bacteriol. 101, 636-642.

Carbonell, L. M., and Rodriguez, J. (1968). Mycelial phase of Paracoccidioides brasiliensis and Blastomyces dermatitidis: an electron microscope study. J. Bacteriol. 96, 533-543.

Casadevall, A., Nosanchuk, J. D., Williamson, P., and Rodrigues, M. L. (2009). Vesicular transport across the fungal cell wall. Trends Microbiol. $17,158-162$.

Castro, N. S., de Castro, K. P., Orlandi, I., Feitosa, L. S., Rosa e Silva, L. K., Vainstein, M. H., Bao, S. N., Vai, M., and Soares, C. M. (2009). Characterization and functional analysis of the beta-1,3-glucanosyltransferase 3 of the human pathogenic fungus Paracoccidioides brasiliensis. FEMS Yeast Res. 9, 103-114.

Castro, N. S., Maia, Z. A., Pereira, M., and Soares, C. M. (2005). Screening for glycosylphosphatidylinositolanchored proteins in the Paracoccidioides brasiliensis transcriptome. Genet. Mol. Res. 4, 326-345.

Chaudhuri, R., Ansari, F. A., Raghunandanan, M. V., and Ramachandran, S. (2011). FungalRV: adhesin prediction and immunoinformatics portal for human fungal pathogens. BMC Genomics 12, 192. doi:10.1186/1471-2164-12-192

Coltri, K. C., Casabona-Fortunato, A. S., Gennari-Cardoso, M. L., Pinzan, C. F., Ruas, L. P., Mariano, V. S., Martinez, R., Rosa, J. C., PanuntoCastelo, A., and Roque-Barreira, M. C. (2006). Paracoccin, a GlcNAcbinding lectin from Paracoccidioides brasiliensis, binds to laminin and induces TNF-alpha production by macrophages. Microbes Infect. 8, 704-713.

Crott, L. S., Lucisano-Valim, Y. M., Silva, C. L., and Barbosa, J. E. (1997). Interactions of $\mathrm{F} 1$ fractions from different strains of Paracoccidioides brasiliensis with human complement and with human neutrophils. Mycopathologia 140, 19-27.

Crott, L. S., Valim, Y. M., Silva, C. L., and Barbosa, J. E. (1993). The role of the complement system in the neutrophil functions stimulated in vitro by an alkali-insoluble cell wall fraction of Paracoccidioides brasiliensis. J. Med. Vet. Mycol. 31, 17-27.

da Silva, C. N., Barbosa, M. S., Maia, Z. A., Bao, S. N., Felipe, M. S., Santana, J. M., Mendes-Giannini, M. J. S., Pereira, M., and Soares, C. M. A. (2008). Characterization of Paracoccidioides brasiliensis PbDfg5p, a cell-wall protein implicated in filamentous growth. Yeast 25, 141-154. da Silva, M. B., Marques, A. F. Nosanchuk, J. D., Casadevall, A., Travassos, L. R., and Taborda, C. P. (2006). Melanin in the dimorphic fungal pathogen Paracoccidioides brasiliensis: effects on phagocytosis, intracellular resistance and drug susceptibility. Microbes Infect. 8, 197-205.

da Silva, M. B., Thomaz, L., Marques, A. F., Svidzinski, A. E., Nosanchuk, J. D., Casadevall, A., Travassos, L. R., and Taborda, C. P. (2009). Resistance of melanized yeast cells of Paracoccidioides brasiliensis to antimicrobial oxidants and inhibition of phagocytosis using carbohydrates and monoclonal antibody to CD18. Mem. Inst. Oswaldo Cruz 104 644-648.

da Silva Neto, B. R., de Fátima da Silva, J., Mendes-Giannini, M. J., Lenzi, H. L., Almeida Soares, C. M., and Pereira, M. (2009). The malate synthase of Paracoccidioides brasiliensis is a linked surface protein that behaves as an anchorless adhesin. BMC Microbiol. 9, 272. doi:10.1186/1471-2180-9-272

de Agostino Biella, C., Uecker, M., Silva, M. F., Barbosa, J. E., Silva, C. L., and Crott, L. S. (2006). Investigation of the role of complement and complement receptors in the modulation of B cell activation by a Paracocidioides brasiliensis cell wall fraction. Clin. Immunol. 118, 324-331.

de Oliveira, S. L., da Silva, M. F. Soares, A. M., and Silva, C. L. (1993). Cell wall fractions from Paracoccidioides brasiliensis induce hypergammaglobulinemia. Mycopathologia 121, 1-5.

de Pádua Queiroz, L. Jr., Mattos, M. E. Jr., da Silva, M. F., and Silva, C. L. (2010). TGF-beta and CD23 are involved in nitric oxide production by pulmonary macrophages activated by beta-glucan from Paracoccidioides brasiliensis. Med. Microbiol. Immunol. 199, 61-69.

Desjardins, C., Champion, M., Holder, J., Muszewsha, A., Goldberg, J., Baptista, A. J., Brígido, M. M., Ferreira, M., Garcia, A., Grynberg, M., Heiman, D., Henn, M., Kodira, C., Leon-Narvaez, H., Longo, L., Ma, L., Malavazi, I., Matsuo, A. Moarais, F., Pereira, M., Brito, S., Sakthikumar, S., Salem-Izacc, S., Sykes, S., Teixeira, M. M., Vallejo, M., Willment, J. A., Young, S., Yandava, C., Zeng, Q., Zucker, J., Felipe, M. S., Goldman, G. H., Haas, B., McEwen, J. G., Nino-Vega, G. A., Puccia, R., San-Blas, G., Soares, C. M., Birren, B., and Cuomo, C. (2011). Comparative genomic analysis of human fungal pathogens causing paracoccidioidomycosis. PLoS Genet. 7, e1002345. doi:10.1371/journal.pgen.1002345

Diniz, S. N., Nomizo, R., Cisalpino, P. S., Teixeira, M. M., Brown, G. D., Mantovani, A., Gordon, S., Reis, L. F., and Dias, A. A. (2004). PTX3 function as an opsonin for the dectin-1-dependent internalization of zymosan by macrophages. $J$. Leukoc. Biol. 75, 649-656.

Donofrio, F. C., Calil, A. C., Miranda, E. T., Almeida, A. M., Benard, G., Soares, C. P., Veloso, S. N., Soares, C. M., and Mendes Giannini, M. J. (2009). Enolase from Paracoccidioides brasiliensis: isolation and identification as a fibronectin-binding protein. J. Med. Microbiol. 58, 706-713.

dos Reis Almeida, F. B., de Oliveira, L. L., Valle de Souza, M, Barreira, M. C., and Hanna, E. S. (2010). Paracoccin from Paracoccidioides brasiliensis; purification through affinity with chitin and identification of $\mathrm{N}$-acetyl-beta-Dglucosaminidase activity. Yeast 27, 67-76.

Edwards, M. R., Salazar, M. E., Samsonoff, W. A., Cano, L. E., Ostrander, G. A., and Restrepo, A. (1991). Electron microscopic study of conidia produced by the mycelium of Paracoccidioides brasiliensis. Mycopathologia 114, 169-177.

Felipe, M. S., Andrade, R. V., Arraes, F. B., Nicola, A. M., Maranhão, A. Q., Torres, F. A., Silva-Pereira, I., Pocas-Fonseca, M. J., Campos, E. G., Moraes, L. M., Andrade, P. A., Tavares, A. H., Silva, S. S., Kyaw, C. M., Souza, D. P., Pereira, M., Jesuíno, R. S., Andrade, E. V., Parente, J. A., Oliveira, G. S., Barbosa, M. S., Martins, N. F., Fachin, A. L., Cardoso, R. S., Passos, G. A., Almeida, N. F., Walter, M. E., Soares, C. M., Carvalho, M. J., and Brígido, M. M. (2005). Transcriptional profiles of the human pathogenic fungus Paracoccidioides brasiliensis in mycelium and yeast cells. J. Biol. Chem. 280, 24706-24714.

Felipe, M. S., Andrade, R. V., Petrofeza, S. S., Maranhão, A. Q., Torres, F. A., Albuquerque, P., Arraes, F. B., Arruda, M., Azevedo, M. O., Baptista, A. J., Bataus, L. A., Borges, C. L., Campos, E. G., Cruz, M. R., Daher, B. S., Dantas, A., Ferreira, M. A., Ghil, G. V., Jesuino, R. S., Kyaw, C. M., Leitão, L., Martins, C. R., Moraes, L. M., Neves, E. O., Nicola, A. M., Alves, E. S., Parente, J. A., Pereira, M., Pocas-Fonseca, M. J., Resende, R., Ribeiro, B. M., Saldanha, R. R., Santos, S. C., Silva-Pereira, I., Silva, M. A., Silveira, E., Simões, I. C., 
Soares, R. B., Souza, D. P., Souza, M. T., Andrade, E. V., Xavier, M. A., Veiga, H. P., Venâncio, E. J., Carvalho, M. J., Oliveira, A. G., Inoue, M. K., Almeida, N. F., Walter, M. E., Soares, C. M., and Brígido, M. M. (2003). Transcriptome characterization of the dimorphic and pathogenic fungus Paracoccidioides brasiliensis by EST analysis. Yeast 20, 263-271.

Figueiredo, F., Alves, L. M., and Silva, C. L. (1993). Tumor necrosis factor production in vivo and in vitro in response to Paracoccidioides brasiliensis and the cell wall fractions thereof. Clin. Exp. Immunol. 93, 189-194.

Ganiko, L., Puccia, R., Mariano, V. S., Sant'Anna, O. A., Freymüller, E., Roque-Barreira, M. C., and Travassos, L. R. (2007). Paracoccin, an $\mathrm{N}$-acetyl-glucosaminebinding lectin of Paracoccidioides brasiliensis, is involved in fungal growth. Microbes Infect. 9, 695-703.

Gantner, B. N., Simmons, R. M., Canavera, S. J., Akira, S., and Underhill, D. M. (2003). Collaborative induction of inflammatory responses by dectin-1 and Tolllike receptor 2. J. Exp. Med. 197, 1107-1117.

Gesztesi, J. L., Puccia, R., Travassos, L. R., Vicentini, A. P., Moraes, J. Z., Franco, M. F., and Lopes, J. D. (1996). Monoclonal antibodies against the 43,000 Da glycoprotein from Paracoccidioides brasiliensis modulate laminin-mediated fungal adhesion to epithelial cells and pathogenesis. Hybridoma 15, 415-422.

Goihman-Yahr, M., Essenfeld-Yahr, E., Albornoz, M. C., Yarzábal, L., Gómez, M. H., San Martín, B., Ocanto, A., Gil, F., and Convit, J. (1980). Defect of in vitro digestive ability of polymorphonuclear leukocytes in paracoccidioidomycosis. Infect. Immun. 28, 557-566.

Goldman, G. H., Marques, E. R., Duarte Ribeiro, D. C., Souza Bernardes, L. A., Quiapin, A. C., Vitorelli, P. M., Savoldi, M., Semighini, C. P., Oliveira, R. C., Nunes, L. R., Travassos, L. R., Puccia, R., Batista, W. L., Ferreira, L. E., Moreira, J. C., Bogossian, A. P., Tekaia, F., Nobrega, M. P., Nobrega, F. G., and Goldman, M. H. (2003). Expressed sequence tag analysis of the human pathogen Paracoccidioides brasiliensis yeast phase: identification of putative homologues of Candida albicans virulence and pathogenicity genes. Eukaryotic Cell 2, 34-48.

Gómez, B. L., Nosanchuk, J. D., Díez, S., Youngchim, S., Aisen, P., Cano, L. E., Restrepo, A., Casadevall, A., and Hamilton, A. J. (2001). Detection of melanin-like pigments in the dimorphic fungal pathogen Paracoccidioides brasiliensis in vitro and during infection. Infect. Immun. 69 , 5760-5767.

González, A., Caro, E., Muñoz, C. Restrepo, A., Hamilton, A. J., and Cano, L. E. (2008). Paracoccidioides brasiliensis conidia recognize fibronectin and fibrinogen which subsequently participate in adherence to human type II alveolar cells: involvement of a specific adhesin. Microb. Pathog. 44, 389-401.

González, A., Gómez, B. L., Diez, S., Hernández, O., Restrepo, A., Hamilton, A. J., and Cano, L. E. (2005). Purification and partial characterization of a Paracoccidioides brasiliensis protein with capacity to bind to extracellular matrix proteins. Infect. Immun. 73, 2486-2495.

Hallak, J., San Blas, F., and San Blas, G. (1982). Isolation and wall analysis of dimorphic mutants of Paracoccidioides brasiliensis. Sabouraudia 20, 51-62.

Hanna, S. A., Monteiro da Silva, J. L., and Giannini, M. J. (2000). Adherence and intracellular parasitism of Paracoccidioides brasiliensis in Vero cells. Microbes Infect. 2, 877-884.

Jiménez, M. P., Restrepo, A., Radzioch, D., Cano, L. E., and García, L. F. (2006). Importance of complement 3 and mannose receptors in phagocytosis of Paracoccidioides brasiliensis conidia by Nrampl congenic macrophages lines. FEMS Immunol. Med. Microbiol. 47, 56-66.

Kanetsuna, F. (1981). Ultrastructural studies on the dimorphism of Paracoccidioides brasiliensis, Blastomyces dermatitidis and Histoplasma capsulatum. Sabouraudia 19, 275-286.

Kanetsuna, F., and Carbonell, L. M. (1970). Cell wall glucans of the yeast and mycelial forms of Paracoccidioides brasiliensis. J. Bacteriol. 101, 675-680.

Kanetsuna, F., Carbonell, L. M., Azuma, I., and Yamamura, Y. (1972). Biochemical studies on the thermal dimorphism of Paracoccidioides brasiliensis. J. Bacteriol. 110, 208-218.

Kanetsuna, F., Carbonell, L. M., Moreno, R. E., and Rodriguez, J. (1969). Cell wall composition of the yeast and mycelial forms of Paracoccidioides brasiliensis. J. Bacteriol. 97, 1036-1041.

Kashino, S. S., Singer-Vermes, L. M., Calich, V. L., and Burger, E. (1990). Alterations in the pathogenicity of one Paracoccidioides brasiliensis isolate do not correlative with its in vitro growth. Mycopathologia 111, 173-180.
Latge, J. P. (2009). Galactofuranose containing molecules in Aspergillus fumigatus. Med. Mycol. 47, S104S109.

Matute, D. R., McEwen, J. G., Puccia, R., Montes, B. A., San Blas, G., Bagagli, E., Rauscher, J. T., Restrepo, A., Morais, F., Niño-Vega, G., and Taylor, J. W. (2006). Cryptic speciation and recombination in the fungus Paracoccidioides brasiliensis as revealed by gene genealogies. $\mathrm{Mol}$. Biol. Evol. 23, 65-73.

McEwen, J. G., Bedoya, V., Patiño, M. M., Salazar, M. E., and Restrepo, A. (1987). Experimental murine paracoccidiodomycosis induced by the inhalation of conidia. J. Med. Vet. Mycol. 25, 165-175.

Mendes-Giannini, M. J., Andreotti, P. F. Vincenzi, L. R., da Silva, J. L., Lenzi, H. L., Benard, G., Zancopé-Oliveira, R., Matos Guedes, H. L., and Soares, C. P. (2006). Binding of extracellular matrix proteins to Paracoccidioides brasiliensis. Microbes Infect. 8, 1550-1559.

Munk, M. E., and Silva, W. D. (1992). Activation of human complement system Paracoccidioides brasiliensis and its deposition on the yeast form cell surface. J. Med. Vet. Mycol. 30, 481-484.

Nakaira-Takahagi, E., Golim, M. A., Bannwart, C. F., Puccia, R., and Peraçoli, M. T. (2011). Interactions between TLR2, TLR4, and mannose receptors with gp43 from Paracoccidioides brasiliensis induce cytokine production by human monocytes. Med. Mycol. 49, 694-703.

Netea, M. G., Brown, G. D., Kullberg, B. J., and Gow, N. A. (2008). An integrated model of the recognition of Candida albicans by the innate immune system. Nat. Rev. Microbiol. 6, 67-78.

Niño-Vega, G. A., Munro, C. A., San Blas, G., Gooday, G. W., and Gow, N. A. (2000). Differential expression of chitin synthase genes during temperature-induced dimorphic transitions in Paracoccidioides brasiliensis. Med. Mycol. 38, 31-39.

Nogueira, S. V., Fonseca, F. L., Rodrigues, M. L., Mundodi, V., Abi-Chacra, E. A., Winters, M. S., Alderete, J. F., and Soares, C. M. (2010). Paracoccidioides brasiliensis enolase is a surface protein that binds plasminogen and mediates interaction of yeast forms with host cells. Infect. Immun. 78, 4040-4050.

Nombela, C., Gil, C., and Chaffin, W. L. (2006). Non-conventional protein secretion in yeast. Trends Microbiol. 14, 15-21.

Nunes, L. R., Oliveira, R. C, Leite, D. B., Silva, V. S., Marques, E. R., Ferreira,
M. E. S., Ribeiro, D. C., Bernardes, L. A. S., Goldman, M. H., Puccia, R., Travassos, L. R., Batista, W. L., Nóbrega, M. P., Nóbrega, F. G., Yang, D. Y., Pereira, C. A. B., and Goldman, G. H. (2005). Transcriptome analysis of Paracoccidioides brasiliensis cells undergoing mycelium-toyeast transition. Eukaryotic Cell 4, 2115-2128.

Oliveira, D. L., Nakayasu, E. S., Joffe, L. S., Guimarães, A. J., Sobreira T. J., Nosanchuk, J. D., Cordero, R. J., Frases, S., Casadevall, A., Almeida, I. C., Nimrichter, L., and Rodrigues, M. L. (2010). Characterization of yeast extracellular vesicles: evidence for the participation of different pathways of cellular traffic in vesicle biogenesis. PLOS ONE 5, e11113. doi:10.1371/journal.pone. 0011113

Pereira, L. A., Báo, S. N., Barbosa, M. S., Silva, J. L., Felipe, M. S., Santana, J. M., Mendes-Giannini, M. J., and Soares, C. M. (2007). Analysis of the Paracoccidioides brasiliensis triosephosphate isomerase suggests the potential for adhesin function. FEMS Yeast Res. 7, 1381-1388.

Puccia, R., and Travassos, L. R. (1991). 43-kilodalton glycoprotein from Paracoccidioides brasiliensis: immunochemical reactions with sera from patients with paracoccidioidomycosis, histoplasmosis, or Jorge Lobo's disease. J. Clin. Microbiol. 29, 1610-1615.

Rappleye, C. A., Eissenberg, L. G., and Goldman, W. E. (2007). Histoplasma capsulatum alpha-(1,3)-glucan blocks innate immune recognition by the beta-glucan receptor. Proc. Natl. Acad. Sci. U.S.A. 104, 1366-1370.

Rappleye, C. A., Engle, J. T., and Goldman, W. E. (2004). RNA interference in Histoplasma capsulatum demonstrates a role for alpha-(1,3)-glucan in virulence. Mol. Microbiol. 53, 153-165.

Rodrigues, M. L., Nimrichter, L., Oliveira, D. L., Frases, S., Miranda, K., Zaragoza, O., Alvarez, M. Nakouzi, A., Feldmesser, M., and Casadevall, A. (2007). Vesicular polysaccharide export in Cryptococcus neoformans is a eukaryotic solution to the problem of fungal transcell wall transport. Eukaryotic Cell 6, 48-59.

Rodrigues, M. L., Travassos, L. R., Miranda, K. R., Franzen, A. J., Rozental, S., Souza, W., Alviano, C. S., and Barreto-Bergter, E. (2000). Human antibodies against a purified glucosylceramide from Cryptococcus neoformans inhibit cell budding and fungal growth. Infect. Immun. 68, 7049-7060. 
Rodríguez-Brito, S., Niño-Vega, G., and San Blas, G. (2010). Caspofungin affects growth of Paracoccidioides brasiliensis in both morphological phases. Antimicrob. Agents Chemother. 54, 5391-5394.

Samsonoff, W. A., Salazar, M. E., McKee, M. L., Restrepo, A., Cano, L. E., and Edwards, M. R. (1991). Scanning electron microscopy of the conidia produced by the mycelial form of Paracoccidioides brasiliensis. Mycopathologia 114, 9-15.

San Blas, F. (1986). Ultrastructure of spore formation in Paracoccidioides brasiliensis. J. Med. Vet. Mycol. 24, 203-210.

San Blas, F., and San Blas, G. (1992). Mutants of Paracoccidioides brasiliensis strain IVIC $\mathrm{Pb} 9$ affected in dimorphism. J. Med. Vet. Mycol. 30, 51-60.

San Blas, F., San Blas, G., and Cova, L. J. (1976). A morphological mutant of Paracoccidioides brasiliensis strain IVIC Pb9. Isolation and wall characterization. J. Gen. Microbiol. 93, 209-218.

San Blas, G. (1982). The cell wall of fungal human pathogens: its possible role in host-parasite relationships. Mycopathologia 79, 159-184.

San Blas, G., and Niño-Vega, G. (2008). Paracoccidioides brasiliensis: chemical and molecular tools for research on cell walls, antifungals, diagnosis, taxonomy. Mycopathologia 165, 183-195.

San Blas, G., Niño-Vega, G., and Iturriaga, T. (2002). Paracoccidioides brasiliensis and paracoccidioidomycosis: molecular approaches to morphogenesis, diagnosis, epidemiology, taxonomy and genetics. Med. Mycol. 40, 225-242.

San Blas, G., Prieto, A., Bernabé, M., Ahrazem, O., Moreno, B., and Leal, J. A. (2005). Alphagalf-1,6-alpha-mannopyranoside side chains in Paracoccidioides brasiliensis cell wall are shared by members of the Onygenales, but not by galactomannans of other fungal genera. Med. Mycol. 43, 153-159.

San Blas, G., and San Blas, F. (1982). Variability of cell wall composition in Paracoccidioides brasiliensis: a study of two strains. Sabouraudia 20,31-40.

San Blas, G., and San Blas, F. (1984). Molecular aspects of fungal dimorphism. Crit. Rev. Microbiol. 11, 101-127.

San Blas, G., and San Blas, F. (1994). "Biochemistry of Paracoccidioides brasiliensis dimorphism," in Paracoccidioidomycosis, eds M. Franco, C. S. Lacaz, A. Restrepo-Moreno, and G.
Del Negro (Boca Raton: CRC Press), 49-66.

San Blas, G., San Blas, F., Ordaz, D., Centeno, S., and Albornoz, M. C. (1984). Chemical changes in cell wall structure of five strains of Paracoccidioides brasiliensis. Sabouraudia 22, 255-257.

San Blas, G., San Blas, F., Ormaechea, E., and Serrano, L. E. (1977a). Cell wall analysis of an adeninerequiring mutant of the yeast-like form of Paracoccidioides brasiliensis strain IVIC Pb9. Sabouraudia 15, 297-303.

San Blas, G., San Blas, F., and Serrano, L. E. (1977b). Host-parasite relationships in the yeastlike form of Paracoccidioides brasiliensis strain IVIC Pb9. Infect. Immun. 15, 343-346.

San Blas, G., and Vernet, D. (1977). Induction of the synthesis of cell wall alpha-1,3-glucan in the yeastlike form of Paracoccidioides brasiliensis strain IVIC $\mathrm{Pb} 9$ by fetal calf serum. Infect. Immun. 15, 897-902.

Silva, C. L., and Fazioli, R. A. (1985). A Paracoccidioides brasiliensis polysaccharide having granuloma-inducing, toxic and macrophage-stimulating activity. $J$. Gen. Microbiol. 131, 1497-1501.

Silva, M. F., Bocca, A. L., Ferracini, R. Jr., Figueiredo, F., and Silva, C. L. (1997). Cellular requirements for immunomodulatory effects caused by cell wall components of Paracoccidioides brasiliensis on antibody production. Clin. Exp. Immunol. 109, 261-271.

Silva, M. F., Napimoga, M. H., Rodrigues, D. B., Pereira, S. A., and Silva, C. L. (2011). Phenotypic and functional characterization of pulmonary macrophages subpopulations after intratracheal injection of Paracoccidioides brasiliensis cell wall components. Immunobiology 216, 821-831.

Silva, M. F., and Silva, C. L. (1995). The role of somatic structure of the fungus Paracoccidioides brasiliensis upon B cell activation in experimental paracoccidioidomycosis. Clin. Exp. Immunol. 101, 321-327.

Soares, R. M., Costa e Silva-Filho, F., Rozental, S., Angluster, J., Souza, W., Alviano, C. S., and Travassos, L. R. (1998). Anionogenic groups and surface sialoglycoconjugate structures of yeast forms of the human pathogen Paracoccidioides brasiliensis. Microbiology 144, 309-314.

Sorais, F., Barreto, L., Leal, J. A., Bernabé, M., San Blas, G., and NiñoVega, G. A. (2010). Cell wall glucan synthases and GTPases in Paracoccidioides brasiliensis. Med. Mycol. 48, $35-47$.
Straus, A. H., Freymüller, E., Travassos, L. R., and Takahashi, H. K. (1996). Immunochemical and subcellular localization of the $43 \mathrm{kDa}$ glycoprotein antigen of Paracoccidioides brasiliensis with monoclonal antibodies. J. Med. Vet. Mycol. 34, 181-186.

Sturme, H., Puccia, R., Goldman, G. H. and Rodrigues, F. (2011). Molecular biology of the dimorphic fungi Paracoccidioides spp. Fungal Biol. Rev. 25, 89-97.

Taborda, C. P., Juliano, M. A., Puccia, R., Franco, M., and Travassos, L. R. (1998). Mapping of the T-cell epitope in the major 43 kilodalton glycoprotein of Paracoccidioides brasiliensis which induces a Th-1 response protective against fungal infection in $\mathrm{BALB} / \mathrm{c}$ mice. Infect. Immun. 66, 786-793.

Tacco, B. A., Parente, J. A., Barbosa, M. S., Báo, S. N., Góes, T. D., Pereira, M., and Soares, C. M. (2009). Characterization of a secreted aspartyl protease of the fungal pathogen Paracoccidioides brasiliensis. Med. Mycol. 47, 845-854.

Takahashi, H. K., Toledo, M. S., Suzuki, E., Tagliari, L., and Straus, A. H. (2009). Current relevance of fungal and trypanosomatid glycolipids and sphingolipids: studies defining structures conspicuously absent in mammals. An. Acad. Bras. Cienc. 81, 477-488.

Teixeira, M. M., Theodoro, R. C., Carvalho, M. J., Fernandes, L., Paes, H. C., Hahn, R. C., Mendoza, L., Bagagli, E., San Blas, G., and Felipe, M. S. (2009). Phylogenetic analysis reveals a high level of speciation in the Paracoccidioides genus. Mol. Phylogenet. Evol. 52, 273-283.

Toledo, M. S., Suzuki, E., Levery, S. B., Straus, A. H., and Takahashi, H. K. (2001). Characterization of monoclonal antibody MEST-2 specific to glucosylceramide of fungi and plants. Glycobiology 11, 105-112.

Toledo, M. S., Tagliari, L., Suzuki, E. Silva, C. M., Straus, A. H., and Takahashi, H. K. (2010). Effect of antiglycosphingolipid monoclonal antibodies in pathogenic fungal growth and differentiation. Characterization of monoclonal antibody MEST3 directed to Manp-alpha1, 3-Manp alpha1,2 IPC. BMC Microbiol. 10, 47. doi:10.1186/1471-2180-10-47

Tomazett, P. K., Cruz, A. H., Bonfim, S. M., Soares, C. M., and Pereira, M. (2005). The cell wall of Paracoccidioides brasiliensis: insights from its transcriptome. Genet. Mol. Res. 4 309-325.

Tomazett, P. K., Félix, C. R., Lenzi, H. L., Faria, F. P., Soares, C. M., and Pereira,
M. (2010). 1,3-beta-D-Glucan synthase of Paracoccidioides brasiliensis: recombinant protein, expression and cytolocalization in the yeast and mycelium phases. Fungal Biol. 114, 809-816.

Travassos, L. R., Rodrigues, E. G., Iwai, L. K., and Taborda, C. P. (2008). Attempts at a peptide vaccine against paracoccidioidomycosis, adjuvant to chemotherapy. Mycopathologia 165, 341-352.

Vallejo, M. C., Matsuo, A. L., Ganiko, L. Medeiros, L. C., Miranda, K., Silva, L. S., Freymüller-Haapalainen, E., Sinigaglia-Coimbra, R., Almeida, I. C., and Puccia, R. (2011). The pathogenic fungus Paracoccidioides brasiliensis exports extracellular vesicles containing highly immunogenic alpha-Galactosyl epitopes. Eukaryotic Cell 10, 343-351.

Vicentini, A. P., Gesztesi, J. L., Franco, M. F., Souza, W., Moraes, J. Z., Travassos, L. R., and Lopes, J. D. (1994). Binding of Paracoccidioides brasiliensis to laminin through surface glycoprotein gp43 leads to enhancement of fungal pathogenesis. Infect. Immun. 62, 1465-1469.

Xander, P., Vigna, A. F., Feitosa, L. S., Pugliese, L., Bailão, A. M., Soares, C. M., Mortara, R. A., Mariano, M., and Lopes, J. D. (2007). A surface $75-\mathrm{kDa}$ protein with acid phosphatase activity recognized by monoclonal antibodies that inhibit Paracoccidioides brasiliensis growth. Microbes Infect. 9, 1484-1492.

Conflict of Interest Statement: The authors declare that the research was conducted in the absence of any commercial or financial relationships that could be construed as a potential conflict of interest.

Received: 20 September 2011; paper pending published: 13 October 2011; accepted: 02 December 2011; published online: 20 December 2011.

Citation: Puccia R, Vallejo MC, Matsuo $A L$ and Longo LVG (2011) The Paracoccidioides cell wall: past and present layers toward understanding interaction with the host. Front. Microbio. 2:257. doi: 10.3389/fmicb.2011.00257

This article was submitted to Frontiers in Fungi and Their Interactions, a specialty of Frontiers in Microbiology.

Copyright (c) 2011 Puccia, Vallejo, Matsuo and Longo. This is an open-access article distributed under the terms of the Creative Commons Attribution Non Commercial License, which permits noncommercial use, distribution, and reproduction in other forums, provided the original authors and source are credited. 